\title{
Hepatitis B virus genotypes, precore and core promoter variants among predominantly Asian patients with chronic HBV infection in a Canadian center
}

Fung SK, Wong FSH, Wong DKH, Hussain MT, Lok ASF. Hepatitis B virus genotypes, precore and core promoter variants among predominantly Asian patients with chronic HBV infection in a Canadian center.

Liver International 2006: 26: 796-804.

(C) 2006 The Author. Journal compilation (C) 2006 Blackwell Munksgaard

Abstract: Background and Aims: The epidemiology of hepatitis B virus (HBV) infection in North America may be changing as a result of immigration from endemic countries. The purpose of this study was to determine the prevalence of $\mathrm{HBV}$ genotypes, precore (PC) and core promoter (CP) variants, and the proportion of patients meeting treatment criteria for HBV. Methods: A cross-sectional study of consecutive HBV patients attending a Canadian tertiary liver center was conducted. HBV DNA was quantified by polymerase chain reaction assay. HBV genotypes and variants were determined using a line probe assay. Results: Two hundred and seventy-two patients were enrolled; 200 were not receiving treatment at enrollment, of whom 116 were men and 84 women with a mean age $42 \pm 14$ years. Among this group, $177(88 \%)$ patients were Asian and $19(10 \%)$ were Caucasian and $69(35 \%)$ patients were hepatitis B e antigen ( $\mathrm{HBeAg})$ positive. Genotypes $\mathrm{B}$ and $\mathrm{C}$ were found in $42 \%$ and $50 \%$ untreated patients, respectively; while $\mathrm{CP}$ and $\mathrm{PC}$ were detected in $52 \%$ and $43 \%$ patients, respectively. Approximately $20 \%$ patients not receiving treatment $(29 \%$ HBeAg positive, $14 \% \mathrm{HBeAg}$ negative) met AASLD guidelines for antiviral therapy. If lower cutoff values for alanine aminotransferase and HBV DNA levels were used, $49 \%$ patients would qualify for treatment. Conclusions: The vast majority of patients at a Canadian tertiary referral center were Asian. Virological and clinical characteristics of these patients reflect their country of origin. Our findings highlight the need to monitor the changing patterns of HBV infection in countries with large immigrant populations.
Scott K. Fung ${ }^{1,2}$, Florence S. H. Wong $^{1}$, David K. H. Wong ${ }^{1}$, Munira T. Hussain ${ }^{2}$ and Anna S. F. Lok ${ }^{2}$

${ }^{1}$ Department of Medicine, University of Toronto, Toronto, ON, Canada, ${ }^{2}$ Division of Gastroenterology, University of Michigan, Ann Arbor, MI, USA

Key words: antiviral therapy - core promoter variant - HBV DNA - HBV genotypes - hepatitis $B$ virus - precore variant

Anna S. Lok, MD, University of Michigan Medical Center, 3912 Taubman Center, Ann Arbor, MI 48109-0362, USA.

Tel: +7346154628

Fax: +734936 7392

e-mail: aslok@umich.edu

Received 5 March 2006, accepted 26 April 2006
There is a paucity of data on the epidemiology and natural history of hepatitis B in North America. Previous studies have focused on indigenous populations in Alaska and Canadian Inuit or First Nations communities (1-3). Although the overall incidence of acute hepatitis $\mathrm{B}$ in

\footnotetext{
Abbreviations: HBV, hepatitis B virus; DNA, deoxyribonucleic acid; ALT, alanine aminotransferase; $\mathrm{HBeAg}$, hepatitis $\mathrm{B}$ e antigen; HBsAg, hepatitis B surface antigen; PCR, polymerase chain reaction; $\mathrm{PC}$, precore; $\mathrm{CP}$, core promoter; $\mathrm{HCC}$, hepatocellular carcinoma; IU, international units; ULN, upper limit of normal; SD, standard deviation.
}

the United States has decreased as a result of vaccination, chronic hepatitis $\mathrm{B}$ virus (HBV) infection remains prevalent in high-risk groups such as immigrants from endemic areas, injection drug users and human immunodeficiency virus (HIV)-infected persons (4).

The prevalence of HBV genotypes varies with geographical location; genotypes $\mathrm{A}$ and $\mathrm{D}$ are most common in Europe, while genotypes B and $\mathrm{C}$ are prevalent in Asia $(5,6)$. Several HBV genotypes can be further classified into subtypes. For example, genotype B is divided into two subtypes: $B a$ (Asia) which shows recom- 


\section{HBV genotypes and variants in Canada}

bination with genotype $\mathrm{C}$ in the precore $(\mathrm{PC}) /$ core promoter $(\mathrm{CP})$ region and $B j$ (Japan) which does not have recombination with other genotypes $(7,8)$. Subtype $B j$ is found almost exclusively in Japan whereas subtype $B a$ can be found in many Asian countries (9). HBV genotypes have been shown to play a role in liver disease and response to antiviral therapy $(10,11)$. For example, HBV genotype B has been associated with hepatitis $\mathrm{B}$ e antigen $(\mathrm{HBe} \mathrm{Ag})$ seroconversion at an earlier age, less active liver disease, slower progression to cirrhosis and a higher rate of $\mathrm{HBeAg}$ response to interferon therapy compared with genotype C (12-14).

PC stop [G1986A] and CP [A1762T+G1764A] mutations are the most common naturally occurring $\mathrm{HBV}$ variants. These mutations diminish or abolish production of $\mathrm{HBe} \mathrm{Ag}$, and are commonly found in patients with $\mathrm{HBeAg}$ negative chronic hepatitis $(15,16)$. PC and $\mathrm{CP}$ variants are common in Europe and Asia but until recently were thought to be rare in North America $(17,18)$. These variants have been reported to be associated with more active liver disease and increased risk of hepatocellular carcinoma, although they have also been found in inactive carriers $(19,20)$.

A recent study of almost 700 patients with chronic HBV infection in the United States found that $65 \%$ of patients were born outside the United States. All major genotypes were present and there was a strong correlation between HBV genotypes and race and country of birth (21). Contrary to earlier studies, PC and CP variants were common, being found in $27 \%$ and $44 \%$ patients, respectively, indicating that $\mathrm{HBeAg}$ negative chronic hepatitis may be on the rise in the United States (22). The prevalence of chronic $\mathrm{HBV}$ infection in the United States is estimated to be $0.5 \%$ based on NHANES III conducted in 1988-1994. However, very few Asian Americans were included in that survey. Studies conducted among Chinese Americans in California in 2001 showed that prevalence of chronic HBV infection was approximately $10 \%(23,24)$. These data suggest that the prevalence of chronic hepatitis $\mathrm{B}$ in the United States may remain high due to immigration from $\mathrm{HBV}$-endemic countries, and the serologic and virologic profiles of patients with chronic HBV infection in the United States reflect the country of birth.

The aims of this study were to determine the distribution of HBV genotypes, the prevalence of $\mathrm{HBeAg}, \mathrm{PC}$ and $\mathrm{CP}$ variants among patients with chronic HBV infection; and to estimate the proportion of patients seen in a large Canadian urban tertiary referral center who meet current practice guidelines for antiviral treatment $(25,26)$.

\section{Patients and methods}

\section{Patients and initial evaluation}

A cross-sectional study of consecutive patients with chronic HBV infection seen by two hepatologists (FSHW and DKHW) at the University Health Network, Toronto, Canada from July 2003 to February 2004 was performed. All adult patients who were HBsAg positive for at least 6 months were eligible for the study. Patients were enrolled irrespective of $\mathrm{HBeAg}$ status, alanine aminotransferase (ALT) level, HBV DNA level or antiviral treatment status. Patients were excluded for hepatitis C virus (HCV), hepatitis D virus (HDV) or HIV coinfection and for concomitant causes of liver disease including alcohol consumption $>50 \mathrm{~g} /$ day. Written informed consent was obtained from each patient, and approval for this study was obtained from the Research Ethics Board at the University Health Network in Toronto and the Institutional Review Board at the University of Michigan in Ann Arbor, MI.

All patients were tested for $\mathrm{HBeAg}$, antibody to $\mathrm{HBeAg}$ (anti-HBe), HBV DNA by polymerase chain reaction (PCR) assay, liver panel [aspartate aminotransferase (AST), ALT (upper limit of normal [ULN], $40 \mathrm{IU} / 1$ ), alkaline phosphatase (ALP), albumin and total bilirubin], complete blood count, international normalized ratio (INR), and $\alpha$-fetoprotein (AFP). An abdominal ultrasound was also performed to determine if there were features of cirrhosis: coarse liver architecture, nodular liver surface or a blunt liver edge and splenomegaly and to detect liver tumors. Liver biopsy was performed based on clinical indications. HBV serology was tested using commercial enzyme-linked immunosorbent assays from Abbott Laboratories (North Chicago, IL). An extra tube of blood was collected, spun, divided into aliquots and stored at $-80{ }^{\circ} \mathrm{C}$ to determine $\mathrm{HBV}$ genotype and $\mathrm{PC}$ and $\mathrm{CP}$ variants in patients not receiving antiviral therapy. Patients receiving antiviral therapy were likely to have undetectable or very low levels of HBV DNA which would preclude determination of HBV genotype, $\mathrm{PC}$ and $\mathrm{CP}$ variants. In addition, sequences in the $\mathrm{PC}$ and $\mathrm{CP}$ regions may have been affected by treatment.

\section{Clinical data}

Clinical data obtained at enrollment included ethnicity, country of birth, family history of HBV infection and hepatocellular carcinoma, prescription and over-the-counter medication usage, previous or current antiviral treatment for HBV, alcohol consumption and current symptoms. 


\section{Fung et al.}

\section{HBV DNA quantification}

Serum samples were shipped to the University of Michigan (laboratory of ASFL) for quantification of HBV DNA using a PCR assay, COBAS Amplicor HB Monitor Assay (Roche, Branchburg, NJ), with a lower limit of detection of 200 copies $/ \mathrm{ml}(40 \mathrm{IU} / \mathrm{ml})$.

Determination of HBV genotype and subtype and detection of $\mathrm{PC}$ and $\mathrm{CP}$ variants

All samples from patients not receiving antiviral treatment that had detectable HBV DNA were tested for HBV genotypes and PC (G1896A) and CP (A1762T and G1764A) mutations. HBV DNA was extracted using methods described previously $(27,28)$. HBV genotype, PC and CP mutations were determined by a line probe assay (InnoLiPA HBV Genotype assay and InnoLiPA HBV PC assay; InnoGenetics Inc., Ghent, Belgium) (29). Subtyping of genotype B samples was performed by direct sequencing. Briefly, HBV DNA was extracted and the PC and core region was amplified during one round of PCR as described previously (27). Specific primers used for PCR were P1 (sense) 5'-TCG CAT GGA GAC CAC CGT GA-3' (nt 1603-1624) and P2 (antisense) 5'-GAG TGC GAA TCC ACA CTC CA-3' (nt 2285-2266). Bidirectional automated sequencing was performed at the DNA sequencing core facility (University of Michigan Medical Center, Ann Arbor, MI) using the standard protocol for the Applied Biosystems DNA Sequencer 377 (Perkin Elmer Corp., Foster City, CA). P1 (sense) primer was used for sequencing. Isolates were classified as $B a$ or $B j$ based on sequence divergence in the $\mathrm{PC}$ and core region of the HBV genome. Isolates were classified as $\mathrm{Ba}$ based on the detection of T1740, G1752, G1764, A1838, G2020 and C2167, whereas Bj had C1740, C1799, G1838, A2020 and T2167 (7). Subtypic classification was further verified by comparison with reference sequences in a phylogenetic analysis using LaserGene software version 5.07 (DNASTAR, Madison, WI).

\section{Statistics}

Statistical testing was performed using SPSS version 13.0 (SPSS Inc., Chicago, IL). For comparison of continuous variables, the two-tailed Student's $t$-test was used. The two-tailed $\chi^{2}$ test was used to compare categorical data. Binary logistic regression was used to test for factors predictive of both elevated ALT $(\geq 1 \times \mathrm{ULN}$, $40 \mathrm{IU} / 1)$ and high HBV DNA ( $\geq 5 \log _{10}$ copies/ $\mathrm{ml})$, elevated ALT $(\geq 1 \times \mathrm{ULN})$ alone and high
HBV DNA ( $\geq 5 \log _{10}$ copies/ml) alone in a multivariable analysis. Variables tested included age, gender, HBV genotype, $\mathrm{HBeAg}$ status, PC and CP variants, ALT and HBV DNA levels, where appropriate. HBV DNA levels were logarithmically transformed for analysis. $P$-values $\leq 0.05$ were considered statistically significant.

\section{Results}

Baseline characteristics

In total, 272 consecutive patients with chronic $\mathrm{HBV}$ infection were seen during the study period. Seventy-two patients $(26 \%)$ were on antiviral therapy at enrollment (Table 1); the majority $(>90 \%)$ was taking lamivudine and the remainder interferon- $\alpha$. The mean age of the patients on treatment was $47 \pm 14$ years and $44(61 \%)$ were male. Most patients in the treated group (93\%) were Asians born outside of Canada. At the time treatment was initiated, $31(43 \%)$ patients were $\mathrm{HBe} \mathrm{Ag}$ positive, median ALT was $73 \mathrm{IU} / 1$ (range, 16-932 IU/1) and mean HBV DNA was $6.1 \pm$ $1.8 \log _{10}$ copies $/ \mathrm{ml}$.

Baseline characteristics of the remaining 200 patients not receiving antiviral therapy are also shown in Table 1. Among this group, the mean age of the patients was $42 \pm 14$ years, and more than half $(58 \%)$ were men. The predominant ethnic group was Asian (88\%), followed by Caucasian $(10 \%)$ and others $(2 \%)$. Most patients were born in China (47\%), Hong Kong (17\%), Vietnam $(13 \%)$ or other countries in Southeast Asia (4\%). Only 13 patients $(5 \%)$ were born in Canada. Sixty-nine $(35 \%)$ patients were $\mathrm{HBeAg}$ positive, while the remaining $131(65 \%)$ were

Table 1. Characteristics of patients

\begin{tabular}{lll}
\hline & Untreated & Treated* \\
\hline Total patients & 200 & 72 \\
Mean age \pm SD (years) & $42 \pm 14$ & $47 \pm 14 \dagger$ \\
Male (\%) & $116(58)$ & $44(61)$ \\
Race & & \\
$\quad$ Asian (\%) & $177(88)$ & $67(93)$ \\
Caucasian (\%) & $19(10)$ & $5(7)$ \\
$\quad$ African Canadian (\%) & $4(2)$ & $0(0)$ \\
Canadian born (\%) & $13(5)$ & $4(6)$ \\
HBeAg positive (\%) & $69(35)$ & $31(43)$ \\
Median ALT (range) (IU/I) & $41(3-1075)$ & $73(16-932) \ddagger$ \\
Mean HBV DNA \pm SD (log copies/ml) & $5.9 \pm 2.4$ & $6.1 \pm 1.8$ \\
Cirrhosis by US (\%) & $33 / 155(21)$ & $\mathrm{NA}$ \\
Antiviral treatment & & \\
$\quad$ Interferon & - & 4 \\
Lamivudine & - & 68
\end{tabular}

*Characteristics at the time antiviral treatment was started. $\dagger P=0.02$. $\ddagger P<0.001$. NA, not available; $\mathrm{HBeAg}$, hepatitis $\mathrm{B}$ e antigen; HBV, hepatitis $B$ virus. 


\section{HBV genotypes and variants in Canada}

$\mathrm{HBeAg}$ negative. Ultrasound features of cirrhosis were observed in 33 of $155(21 \%)$ patients.

Compared with the treated patients, the patients not receiving antiviral treatment were younger (42 \pm 14 vs. $47 \pm 14$ years, $P=0.02)$ and had lower median ALT level (41 vs. $73 \mathrm{IU} /$ $1, P<0.001)$. There was no significant difference between the two groups in terms of gender, $\mathrm{HBeAg}$ status or HBV DNA levels.

\section{HBV genotypes, PC and CP variants}

HBV DNA was detectable in $160(80 \%)$ patients not receiving antiviral treatment. HBV genotype was determined in 151 patients; the remaining nine patients had HBV DNA levels $<3 \log _{10}$ copies $/ \mathrm{ml}$. Genotypes B $(42 \%)$ and C $(50 \%)$ predominated, while genotypes $\mathrm{A}, \mathrm{D}$ and others accounted for $3 \%, 3 \%$ and $2 \%$, respectively (Fig. 1). No cases of mixed genotype infection were detected. Subtyping results were obtained in 61 of 64 genotype B isolates; all isolates belonged to subtype $B a$ and no subtype $B j$ was observed (Fig. 2). PC variant was found among $66(43 \%)$ patients, CP variant in $79(52 \%)$ patients, both PC and CP mutations (double variants) in 36 (24\%) patients, while wild-type sequences in both regions were present in only $42(28 \%)$ patients.

\section{Comparison between $\mathrm{HBeAg}$-positive and $\mathrm{HBeAg}$ - negative patients}

Among the 200 patients who were not receiving antiviral therapy, $69(35 \%)$ were $\mathrm{HBeAg}$ positive and $131(65 \%)$ were $\mathrm{HBeAg}$ negative (Table 2). $\mathrm{HBeAg}$-positive patients were significantly younger than $\mathrm{HBeAg}$-negative patients $(35 \pm 12$ vs. $45 \pm 13$ years) but there was no difference in gender between the two groups. Median ALT levels were similar in $\mathrm{HBe} A g$ positive and in $\mathrm{HBeAg}$-negative patients, but the proportion of HBeAg-positive patients with normal ALT $(<1 \times \mathrm{ULN})$ was significantly lower, $35 \%$ vs. $54 \%(P=0.009)$. Mean HBV DNA level was significantly higher among $\mathrm{HBeAg-positive} \mathrm{pa-}$

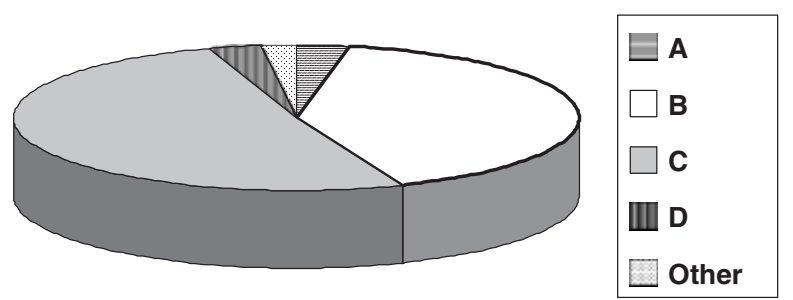

Fig. 1. Distribution of hepatitis B virus (HBV) genotypes. HBV genotypes were determined in 151 patients not receiving antiviral therapy. Genotypes B and $\mathrm{C}$ were most common $(42 \%$ and $50 \%$, respectively); genotypes $\mathrm{A}, \mathrm{D}$ and others accounted for $3 \%, 3 \%$ and $2 \%$, respectively. tients $\left(8.1 \pm 1.5 \log _{10}\right.$ copies $\left./ \mathrm{ml}\right)$ compared to $\mathrm{HBeAg-negative} \mathrm{patients}\left(4.8 \pm 2.0 \log _{10}\right.$ copies/ $\mathrm{ml}$ ), and the proportion of $\mathrm{HBeAg}$-positive patients with $\mathrm{HBV}$ DNA $\geq 5 \log _{10}$ copies $/ \mathrm{ml}$ was also higher ( $96 \%$ vs. $44 \%, P<0.001)$. A higher proportion of $\mathrm{HBeAg}$-negative patients had features of cirrhosis on abdominal ultrasound $(28 \%$ vs. $10 \%, P=0.01)$. $\mathrm{PC}$ and $\mathrm{CP}$ variants were also more common among $\mathrm{HBeAg}$-negative patients $(P<0.001)$.

The distribution of untreated patients according to HBeAg status, ALT levels and HBV DNA levels is illustrated in Fig. 3. Among $69 \mathrm{HBeAg-}$ positive patients, 23 patients had normal ALT, of whom 20 had HBV DNA $\geq 5 \log _{10}$ copies $/ \mathrm{ml}$. Forty-six $\mathrm{HBeAg}$-positive patients had ALT $\geq$ $1 \times \mathrm{ULN}$ and HBV DNA $\geq 4 \log _{10}$ copies $/ \mathrm{ml}$, while 20 had $\mathrm{ALT} \geq 2 \times \mathrm{ULN}$ and $\mathrm{HBV}$ DNA $\geq 5 \log _{10}$ copies/ml. When HBeAg-positive patients with normal ALT were compared with those with elevated ALT, there was no significant difference in age, platelet count, mean HBV DNA levels, HBV genotype or CP variants. However, there was a higher prevalence of males $(60 \%$ vs. $30 \%, P=0.02)$ and a trend towards a higher prevalence of $\mathrm{PC}$ variants $(33 \%$ vs. $13 \%$, $P=0.07)$ in the group with elevated ALT.

Among $131 \mathrm{HBeAg-negative} \mathrm{patients,} 70$ had normal ALT, of whom 53 had HBV DNA $<5 \log _{10}$ copies/ml and 13 had undetectable HBV DNA by PCR. Sixty-one HBeAg-negative patients had elevated ALT, 51 had $\mathrm{ALT} \geq 1 \times \mathrm{ULN}$ and HBV DNA $\geq 4 \log _{10}$ copies $/ \mathrm{ml}$, while 18 had ALT $\geq 2 \times$ ULN and HBV DNA $\geq 5 \log _{10}$ copies $/ \mathrm{ml}$. Compared with patients with normal ALT, those with elevated ALT showed no difference in age, gender, platelet count, HBV genotype, PC or CP mutants. However, mean HBV DNA level was significantly higher among patients with elevated ALT $\left(5.8 \pm 1.9\right.$ vs. $3.9 \pm 1.5 \log _{10}$ copies $\left./ \mathrm{ml}, P<0.001\right)$.

\section{Comparison between patients with genotypes $B$ and $C$}

Comparisons between patients with genotypes B and $\mathrm{C}$ are shown in Table 3. Sixty-five patients were infected with genotype B and 75 with genotype $\mathrm{C}$. The mean age, gender distribution and median ALT levels were not significantly different between the two groups. Genotype C patients had a higher prevalence of $\mathrm{HBeAg}(59 \%$ vs. $37 \%, P=0.01)$ and higher mean HBV DNA level $\quad\left(7.3 \pm 1.6\right.$ vs. $6.6 \pm 1.8 \log _{10}$ copies $/ \mathrm{ml}$, $P=0.03)$. Genotype $\mathrm{C}$ patients were more likely to have $\mathrm{CP}$ variants $(P<0.001)$, whereas genotype $\mathrm{B}$ patients were more likely to have PC variants $(P<0.001)$. Among $\mathrm{HBeAg}$-positive 


\section{Fung et al.}

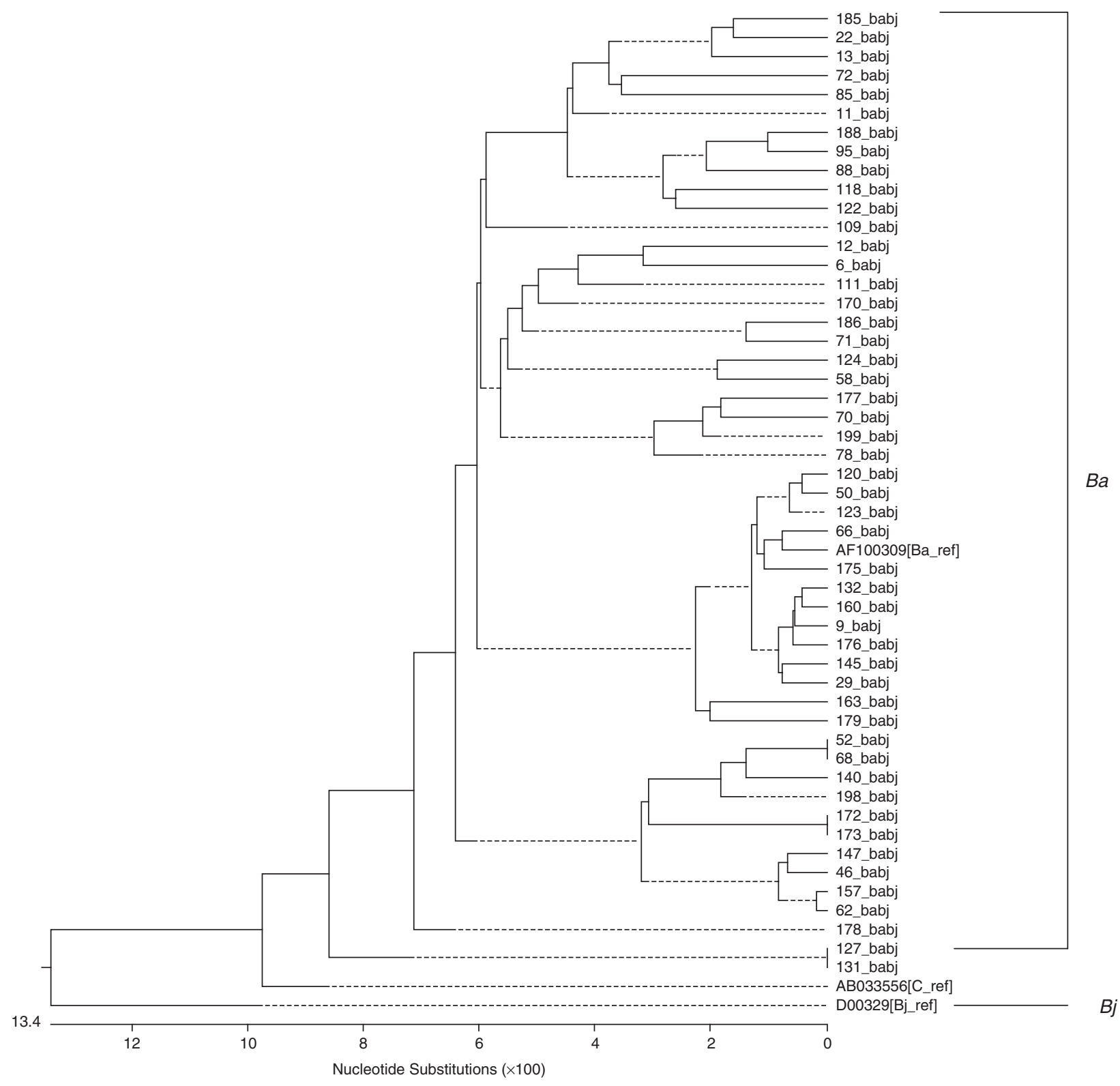

Fig. 2. Subtypes of hepatitis B virus (HBV) genotype B. A phylogenetic analysis of HBV genotype B based on the precore/core region is shown. Sequencing data from 61 patients clustered together with the reference $B a$ strain; no isolates clustered with the reference $B j$ strain.

patients, those with genotype B were significantly younger (31 \pm 9 years) compared with those with genotype C (38 \pm 12 years).

\section{Predictors of elevated ALT and HBV DNA}

When all 200 untreated patients were analyzed, only the presence of HBeAg predicted concomitant elevated ALT $(\geq 1 \times$ ULN) and high HBV DNA $\left(\geq 5 \log _{10}\right.$ copies $\left./ \mathrm{ml}\right)(\mathrm{OR}=2.3,95 \%$ CI 1.1-5.1) (Table 4). When HBeAg-positive patients and $\mathrm{HBeAg}$-negative patients were analyzed separately, male gender and the presence of PC variants were significantly associated with elevated
ALT and high HBV DNA among HBeAg positive and $\mathrm{HBeAg}$-negative patients, respectively.

Predictors of high HBV DNA ( $\geq 5 \log _{10}$ copies/ ml) only included $\mathrm{HBeAg}$ status, ALT $\geq 1 \times$ ULN, and the presence of PC variants (Table 5). Among the $\mathrm{HBeAg}$-positive patients, none of the variables analyzed was predictive of high $\mathrm{HBV}$ DNA, although there was trend for $\mathrm{CP}$ variants $(P=0.06)$. For HBeAg-negative patients, elevated ALT $(\mathrm{OR}=5.3,95 \%$ CI $1.8-15.4)$ and PC variants $(\mathrm{OR}=3.1,95 \%$ CI $1.0-9.7)$ were associated with high HBV DNA.

When all patients were analyzed (Table 6), the only predictor of elevated ALT was HBV 
$\mathrm{DNA} \geq 5 \log _{10}$ copies $/ \mathrm{ml} \quad(\mathrm{OR}=7.2, \quad 95 \% \quad \mathrm{CI}$ 2.5-21.0). Male gender and the presence of PC variants predicted high ALT among $\mathrm{HBeAg}$ positive patients while elevated HBV DNA level was predictive of elevated ALT $(\mathrm{OR}=5.1,95 \%$ CI 1.8-14.6) among HBeAg-negative patients.

\section{Discussion}

In this study, we found that $90 \%$ of patients with chronic HBV infection seen at a Canadian urban tertiary referral liver clinic were Asian and 95\% of patients were born outside Canada. The proportion of patients who were first generation Asians was higher than a recent study in the United States. This may be related to differences in immigration patterns between Canada and the United States, or location of the study. The patients in this study were enrolled from the clinics of two Chinese-Canadian hepatologists in Toronto where approximately $15 \%$ of the population is comprised of immigrants from Asia (30), whereas the US study involved 17 liver centers located all over the country (21).

As expected, in this predominantly Asian population, the vast majority was infected with HBV genotypes $\mathrm{B}$ and $\mathrm{C}$, the most common genotypes in Asia. All the genotype B isolates in this study belonged to subtype $B a$ consistent with the fact that $83 \%$ of the patients were born in China, Hong Kong, Taiwan or Vietnam and none in Japan. In this cross-sectional study, we found that genotype B patients were less likely to be $\mathrm{HBeAg}$ positive and to have lower HBV DNA

Table 2. Comparison of untreated patients by HBeAg status

\begin{tabular}{lllc}
\hline & $\mathrm{HBeAg}+$ & $\mathrm{HBeAg}-$ & $P$-value \\
\hline No. of patients (\%) & 69 & 131 & - \\
Mean age \pm SD (years) & $35 \pm 12$ & $45 \pm 13$ & $<0.001$ \\
Male (\%) & $34(49)$ & $82(63)$ & 0.09 \\
Normal ALT (\%) & $24(35)$ & $71(54)$ & 0.009 \\
Median ALT (range) (IU/I) & $51(3-1054)$ & $36(11-1075)$ & 0.09 \\
Mean platelets \pm SD & $216 \pm 59$ & $200 \pm 60$ & 0.09 \\
$\quad\left(\times 10^{3} / \mathrm{mm}^{3}\right)$ & & & \\
Mean HBV DNA \pm SD & $8.1 \pm 1.5$ & $4.8 \pm 2.0$ & $<0.001$ \\
$\quad\left(\log _{10}\right.$ Copies/ml) & & & \\
HBV DNA $\geq 5 \log _{10}$ & $66(96)$ & $57(44)$ & $<0.001$ \\
$\quad$ copies/ml (\%) & & & \\
HBV DNA $\geq 4 \log _{10}$ & $68(98)$ & $83(63)$ & $<0.001$ \\
$\quad$ Copies/ml (\%) & & & \\
PCR-positive (\%) & $68(98)$ & $102(78)$ & $<0.001$ \\
PC variant (\%) & $18 / 68(26)$ & $48 / 84(57)$ & $<0.001$ \\
CP variant (\%) & $24 / 68(35)$ & $54 / 84(64)$ & $<0.001$ \\
Both PC + CP (\%) & $6 / 68(9)$ & $30 / 84(36)$ & $<0.001$ \\
Wild type (\%) & $32 / 68(47)$ & $10 / 84(12)$ & $<0.001$ \\
Cirrhosis by US (\%) & $6 / 57(10)$ & $27 / 98(28)$ & 0.01 \\
\hline
\end{tabular}

ALT, alanine aminotransferase; HBV, hepatitis B virus; PCR, polymerase chain reaction; $\mathrm{PC}$, precore; $\mathrm{CP}$, core promoter; $\mathrm{HBeAg}$, hepatitis $\mathrm{B}$ e antigen.

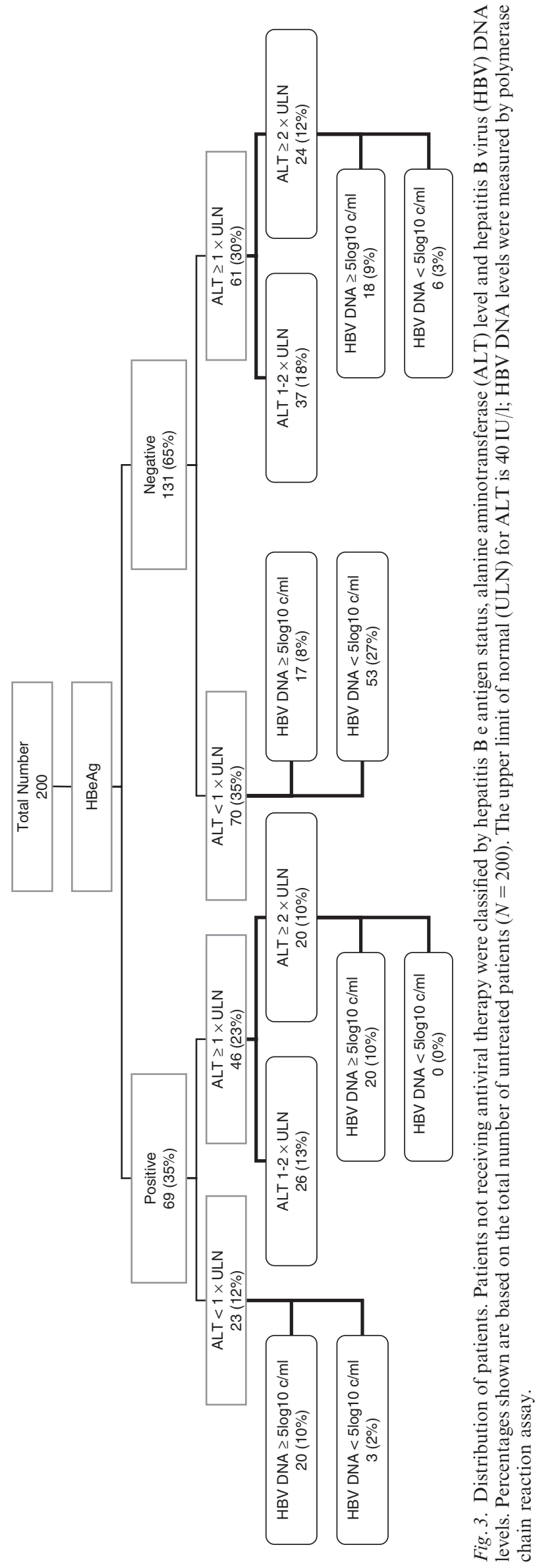




\section{Fung et al.}

Table 3. Comparison of untreated patients with HBV genotype B and genotype C

\begin{tabular}{|c|c|c|c|}
\hline & Genotype B & Genotype C & $P$-value \\
\hline \multicolumn{4}{|l|}{ All patients } \\
\hline No. of patients & 65 & 75 & - \\
\hline Mean age \pm SD (years) & $40 \pm 13$ & $41 \pm 13$ & 0.58 \\
\hline Male $(\%)$ & $32(49)$ & $45(60)$ & 0.28 \\
\hline Median ALT (range) (IU/I) & $47(3-1075)$ & $54(12-1054)$ & 0.35 \\
\hline Abnormal ALT (\%) & $39(60)$ & $50(67)$ & 0.48 \\
\hline $\mathrm{HBeAg}+(\%)$ & $24(37)$ & $44(59)$ & 0.01 \\
\hline Mean HBV DNA \pm SD ( $\log _{10}$ copies/ml) & $6.6 \pm 1.8$ & $7.3 \pm 1.6$ & 0.03 \\
\hline HBV DNA $\geq 5 \log _{10}$ copies/ml $(\%)$ & $49(75)$ & $68(91)$ & 0.02 \\
\hline HBV DNA $\geq 4 \log _{10}$ copies $/ \mathrm{ml}(\%)^{*}$ & $65(100)$ & $75(100)$ & - \\
\hline Mean platelets \pm SD $\left(\times 10^{3} / \mathrm{mm}^{3}\right)$ & $208 \pm 62$ & $208 \pm 58$ & 0.99 \\
\hline $\mathrm{PC}$ variant $(\%)$ & $43(66)$ & $16(21)$ & $<0.001$ \\
\hline $\mathrm{CP}$ variant $(\%)$ & $22(34)$ & $48(64)$ & $<0.001$ \\
\hline Cirrhosis by US (\%) & $10 / 52(19)$ & $12 / 60(20)$ & 0.92 \\
\hline \multicolumn{4}{|l|}{$\mathrm{HBeAg}+$ patients } \\
\hline No. of patients & 24 & 44 & - \\
\hline Mean age \pm SD (years) & $31 \pm 9$ & $38 \pm 12$ & 0.01 \\
\hline Median ALT (range) (IU/I) & $47(3-234)$ & $56(17-1054)$ & 0.31 \\
\hline Abnormal ALT $(\%)$ & $15(63)$ & $30(68)$ & 0.64 \\
\hline Mean HBV DNA \pm SD ( $\log _{10}$ copies/ml) & $8.2 \pm 1.3$ & $8.1 \pm 1.3$ & 0.81 \\
\hline HBV DNA $\geq 5 \log _{10}$ copies/ml $(\%)$ & $23(96)$ & $43(98)$ & 0.77 \\
\hline HBV DNA $\geq 4 \log _{10}$ copies $/ \mathrm{ml}(\%)^{*}$ & $24(100)$ & $44(100)$ & - \\
\hline Mean platelets \pm SD $\left(\times 10^{3} / \mathrm{mm}^{3}\right)$ & $235 \pm 68$ & $205 \pm 52$ & 0.07 \\
\hline Cirrhosis by US (\%) & $1 / 20(5)$ & $5 / 36(14)$ & 0.55 \\
\hline \multicolumn{4}{|l|}{$\mathrm{HBeAg}$ - patients } \\
\hline No. of patients & 41 & 31 & - \\
\hline Mean age \pm SD (years) & $45 \pm 12$ & $46 \pm 13$ & 0.77 \\
\hline Median ALT (range) (IU/I) & $48(17-1075)$ & $50(12-376)$ & 0.52 \\
\hline Abnormal ALT (\%) & $24(59)$ & $19(61)$ & 0.82 \\
\hline Mean HBV DNA \pm SD ( $\log _{10}$ copies/ml) & $5.8 \pm 1.4$ & $6.2 \pm 1.3$ & 0.25 \\
\hline HBV DNA $\geq 5 \log _{10}$ copies/ml $(\%)$ & $26(63)$ & $24(77)$ & 0.34 \\
\hline HBV DNA $\geq 4 \log _{10}$ copies/ml $(\%)^{*}$ & $41(100)$ & $31(100)$ & - \\
\hline Mean platelets \pm SD $\left(\times 10^{3} / \mathrm{mm}^{3}\right)$ & $192 \pm 54$ & $211 \pm 68$ & 0.21 \\
\hline Cirrhosis by US (\%) & $9 / 32(28)$ & $7 / 24(29)$ & 0.93 \\
\hline
\end{tabular}

*For patients in whom genotype could be determined, all had HBV DNA $>3 \log _{10}$ copies/ml. Thus, all patients in this group also had HBV DNA > $4 \log _{10}$ copies/ml. ALT, alanine aminotransferase; HBV, hepatitis B virus; PC, precore; CP, core promoter; HBeAg, hepatitis B e antigen.

Table 4. Predictors of elevated ALT ( $\geq 1 \times$ ULN) and high HBV DNA $\left(\geq 5 \log _{10}\right.$ copies/ml)

\begin{tabular}{lccc}
\hline & OR & $95 \% \mathrm{Cl}$ & $P$-value \\
\hline $\begin{array}{l}\text { All patients } \\
\mathrm{HBeAg}+\end{array}$ & 2.3 & $1.1-5.1$ & 0.04 \\
$\begin{array}{l}\mathrm{HBeAg}+\text { patients } \\
\mathrm{Male}\end{array}$ & 3.8 & $1.1-13.8$ & 0.04 \\
$\mathrm{HBeAg}-$ patients & & $1.1-6.6$ & 0.04 \\
\hline
\end{tabular}

HBeAg, hepatitis B e antigen; PC, precore; ULN, upper limit of normal.

levels. These findings are in accord with previous reports that genotype $\mathrm{B}$ patients undergo $\mathrm{HBeAg}$ seroconversion at a younger age (11).

At the time of enrollment, $26 \%$ of the patients were receiving antiviral therapy. As expected, patients receiving antiviral therapy were more likely to have elevated ALT before treatment than the patients who were not receiving antiviral therapy. However, there was no difference in $\mathrm{HBeAg}$ status and HBV DNA levels between
Table 5. Predictors of high HBV DNA ( $\geq 5 \log _{10}$ copies/ml)

\begin{tabular}{lrll}
\hline & OR & $95 \% \mathrm{Cl}$ & $P$-value \\
\hline All patients & & & \\
HBeAg+ & 18.8 & $2.2-163.0$ & 0.008 \\
ALT $\geq 1 \times$ ULN & 5.8 & $2.0-16.7$ & 0.001 \\
$\quad P C$ variants & 4.0 & $1.3-12.4$ & 0.02 \\
HBeAg + patients & & & \\
$\quad$ CP variants & 9.8 & $1.1-101$ & 0.06 \\
HBeAg - patients & & & \\
ALT $\geq 1 \times$ ULN & 5.3 & $1.8-15.4$ & 0.002 \\
PC variants & 3.1 & $1.0-9.7$ & 0.05
\end{tabular}

HBV, hepatitis B virus; PC, precore; HBeAg, hepatitis B e antigen; ULN, upper limit of normal.

the treated and untreated patients. This may be related to a high $(57 \%)$ proportion of patients receiving treatment for $\mathrm{HBeAg}$ negative chronic hepatitis. It must be emphasized that the decision to treat was based on many factors including serial laboratory values, liver histology, presence of cirrhosis and a history of prior hepatitis flares. Not all of these data were collected, thus we could not analyze factors leading to the decision to treat. 


\section{HBV genotypes and variants in Canada}

Table 6. Predictors of elevated ALT $(\geq 1 \times$ ULN)

\begin{tabular}{lrll}
\hline & OR & $95 \% \mathrm{Cl}$ & $P$-value \\
\hline All patients & & & \\
$\quad$ HBV DNA $\geq 5 \log _{10}$ copies $/ \mathrm{ml}$ & 7.2 & $2.5-21.0$ & $<0.001$ \\
HBeAg + patients & & & \\
$\quad$ PC variants & 18.4 & $1.9-180.3$ & 0.01 \\
$\quad$ Male & 4.3 & $1.1-16.8$ & 0.03 \\
HBeAg - Patients & & & \\
$\quad$ HBV DNA $\geq 5 \log _{10}$ copies $/ \mathrm{ml}$ & 5.1 & $1.8-14.6$ & 0.002 \\
\hline
\end{tabular}

HBV, hepatitis B virus; $\mathrm{HBeAg}$, hepatitis B e antigen; PC, precore; ULN, upper limit of normal.

Reliance on abdominal ultrasound alone without liver biopsy may have led to an underestimation of the prevalence of cirrhosis in this study. Also, due to the heterogeneity in treatment regimens and variations in the duration of treatment, the treated group could not be further analyzed.

Among the patients who were not receiving treatment, $29 \%$ of the $\mathrm{HBeAg}$-positive and $14 \%$ of the HBeAg-negative patients were treatment candidates using cutoff values of ALT $\geq 2 \times \mathrm{ULN}$ and HBV DNA $\geq 5 \log _{10}$ copies $/ \mathrm{ml}$ recommended by current AASLD guidelines, which are similar to European, Asia-Pacific and Canadian guidelines $(26,31-33)$. Given the fluctuating course of chronic HBV infection, it is possible that a higher proportion of patients would meet these criteria during follow-up testing. In addition, some patients with lower ALT and/or HBV DNA levels may be considered for treatment based on histological evidence of moderate/severe inflammation and/or advanced fibrosis. Finally, some investigators have proposed lowering the threshold ALT and HBV DNA levels for initiating antiviral treatment, particularly among $\mathrm{HBeAg}$ negative patients (34). If treatment criteria were expanded to include those with ALT $\geq 1 \times \mathrm{ULN}$ and HBV DNA $\geq 4 \log _{10}$ copies $/ \mathrm{ml}, 49 \%$ would be considered treatment candidates. Together with the $26 \%$ patients who were receiving antiviral therapy at enrollment, we estimate that $40-70 \%$ of patients with chronic HBV infection seen in a tertiary referral liver center would be treatment candidates. However, the proportion of patients with chronic HBV infection in the community that are candidates for antiviral therapy is likely to be substantially lower. As in the US study, we found that most of the patients with chronic HBV infection presenting to a Canadian tertiary referral center were $\mathrm{HBe} A g$ negative. In addition, $\mathrm{PC}$ and $\mathrm{CP}$ variants were found in almost half of our patients, $42 \%$ and $53 \%$ patients, respectively. These findings confirm that $\mathrm{HBeAg}$ negative variants are not uncommon outside of Asia and Southern Europe. Our data are similar to those reported in a previous study of Chinese patients seen in a hepatology clinic in Hong Kong (35).

As a group, the most important predictor of elevated ALT and high HBV DNA level was $\mathrm{HBeAg}$ status: $\mathrm{HBeAg}$-positive patients were two times more likely to have elevated ALT and high HBV DNA compared with HBeAg-negative patients. The degree of observed difference in ALT and HBV DNA levels between HBeAgpositive and $\mathrm{HBeAg}$-negative patients is related to the age of the patients and the referral pattern. Inclusion of a high proportion of young patients with perinatally acquired HBV infection, who are in the immune tolerant phase, will skew the $\mathrm{HBeAg}$-positive group towards high HBV DNA but low ALT levels, while inclusion of a high proportion of patients in the inactive carrier phase will skew the HBeAg-negative group towards low HBV DNA and ALT levels. Lack of an association between $\mathrm{CP}$ variants and liver disease among all patients may be related to use of single time-point laboratory values and relatively short follow-up.

In summary, we found that most patients with chronic HBV infection seen in an urban tertiary liver clinic in Canada were Asian immigrants. We acknowledge that the Asian background of the two hepatologists in this clinic may have led to a referral bias. However, other studies in North America have confirmed that the pattern of HBV infection is largely dictated by immigration from endemic countries $(21,36)$. In this predominantly Asian cohort, the prevalence of HBV genotypes and $\mathrm{PC}$ and $\mathrm{CP}$ variants mimics that seen in Asian countries $(17,35)$. Based on a single evaluation, approximately $20 \%$ of patients $(29 \%$ $\mathrm{HBeAg}$ positive and $14 \% \mathrm{HBeAg}$ negative) that are currently not receiving antiviral therapy meet current AASLD guidelines for treatment. Because of the fluctuating course of chronic HBV infection, patients who do not meet criteria for initiation of treatment during initial evaluation should be closely monitored as HBV DNA and ALT levels may increase during follow-up.

\section{Acknowledgements}

The authors wish to thank all patients who participated in this study. The authors are also grateful to Dr. Erwin Sablon (InnoGenetics Inc.) for supplying reagents and kits for $\mathrm{HBV}$ genotyping and detection of $\mathrm{PC}$ and $\mathrm{CP}$ variants and to Ms. Anna Law, Nina Chan, Grace Wong and Susan Thomas (University Health Network) for assistance during the study. This study was supported by grants from the Canadian Institutes of Health Research, the Canadian Association for the Study of the Liver, GlaxoSmithKline Canada, Schering Canada and Hepatitis Foundation International. Dr. Lok is a paid consultant and has received research support from GlaxoSmithKline, Bristol-Myers Squibb, Gilead, Idenix, Roche and InnoGenetics. 


\section{Fung et al.}

\section{References}

1. McMahon B, Alberts S R, Wainwright R B, Bulkow L, LANiER A P. Hepatitis B-related sequelae: prospective study in 1400 hepatitis B surface antigen-positive Alaskan native carriers. Arch Internal Med 1990; 150: 1051-4.

2. McMahon B, Holck P, Bulkow L, Snowball M M. Serologic and clinical outcomes of 1536 Alaska natives chronically infected with hepatitis B virus. Ann Internal Med 2001; 135: 759-68.

3. Minuk G, Uhanova J. Viral hepatitis in the Canadian Inuit and First Nations populations. Can J Gastroenterol 2003; 17: 707-12.

4. Miller J, Finelli L, Bell B P. Incidence of acute hepatitis B - United States, 1990-2002. J Am Med Assoc 2004; 291: 416-47.

5. Lindh M, Andersson A, Gusdal A. Genotypes, nt 1858 variants, and geographic origin of hepatitis B virus - large scale analysis using a new genotyping method. J Infect Dis 1997; 175: 1285-93.

6. Magnius L O, Norder H. Subtypes, genotypes and molecular epidemiology of the hepatitis B virus as reflected by sequence variability of the S-gene. Intervirology 1995; 38: 24-34.

7. Sugauchi F, Orito E, Ichida T, et al. Hepatitis B virus of genotype $\mathrm{B}$ with or without recombination with genotype $\mathrm{C}$ over the precore region plus the core gene. J Virol 2002; 76 : 5985-92.

8. Sugauchi F, Kumada H, Sakugawa H, et al. Two subtypes of genotype $\mathrm{B}(\mathrm{Ba}$ and $\mathrm{Bj})$ of hepatitis $\mathrm{B}$ virus in Japan. Clin Infect Dis 2004; 38: 1222-8.

9. Sugauchi F, Orito E, Ichida T, et al. Epidemiologic and virologic characteristics of hepatitis $\mathrm{B}$ virus genotype $\mathrm{B}$ having the recombination with genotype C. Gastroenterology 2003; 124: 925-32.

10. Janssen H L, Senturk H, Zeuzem $\mathrm{S}$, et al. Peginterferon alfa- $2 b$ and lamivudine combination therapy compared with peginterferon alfa-2b for chronic $\mathrm{HBeAg-positive} \mathrm{chronic}$ hepatitis B: a randomized controlled trial in 307 patients (abstract). Hepatology 2003; 38:(Suppl): 246A.

11. Chu C, Hussain M, LoK A. Hepatitis B virus genotype B is associated with earlier spontaneous seroconversion than hepatitis B virus genotype C. Gastroenterology 2003; 122: 1756-62.

12. Chan H Ly, Wong M L, Hui A Y, Hung L C T, Chan F K L, Sung J J Y. Hepatitis B virus genotype C takes a more aggressive disease course than hepatitis $\mathrm{B}$ virus genotype B in hepatitis B e antigen-positive patients. J Clin Microbiol 2003; 41: 1277-9.

13. Yuen M F, Fung S K, TANAKa Y, et al. Longitudinal study of hepatitis activity and viral replication before and after $\mathrm{HBeAg}$ seroconversion in chronic hepatitis B patients infected with genotypes B and C. J Clin Microbiol 2004; 42: 5036-40.

14. Janssen H L, van Zonneveld M, Senturk H, et al. Pegylated interferaon alpha-2b alone or in combination with lamivudine for $\mathrm{HBeAg}$-positive chronic hepatitis $\mathrm{B}$ : a randomised trial. Lancet 2005; 365: 123-9.

15. Carman W F, Jacyna M R, HadziYannis S, et al. Mutation preventing formation of hepatitis $\mathrm{B}$ e antigen in patients with chronic hepatitis B infection. Lancet 1989; 2: 588-91.

16. Naoumov N V, Schneider R, Grotzinger T, et al. Precore mutant hepatitis B virus infection and liver disease. Gastroenterology 1992; 102: 538-43.

17. Chu C M, Chiu C T, Sheen I S, Liaw Y F, Yeh C T. Precore mutant of hepatitis $\mathrm{B}$ virus prevails in acute and chronic infections in an area in which hepatitis B is endemic. J Clin Microbiol 1996; 34: 1815-8.

18. Laras A, Koskinas J, Avgidis K, Hadziyannis S J. Incidence and clinical significance of hepatitis $\mathrm{B}$ virus precore gene translation initiation mutations in e antigennegative patients. J Viral Hepatitis 1998; 5: 241-8.

19. Brunetto M R, Oliveri F, Rocca G, et al. Natural course and response to interferon of chronic hepatitis $B$ accompanied by antibody to hepatitis B e antigen. Hepatology 1989; 10: 198-202.

20. Grandjacques C, Paradat P, Stuyver L, et al. Rapid detection of genotypes and mutations in the pre-core promoter and the pre-core region of hepatitis B virus genome: correlation with viral persistence and disease severity. J Hepatol 2000; 33: 430-9.

21. Chu C J, Keefe E, Han S H, et al. Hepatitis B virus genotypes in the United States: results of a nationwide study. Gastroenterology 2003; 125: 444-51.

22. Chu C J, Keeffe E, Han S H, et al. Prevalence of HBV precore/core promoter variants in the United States. Hepatology 2003; 38: 619-28.

23. Anonymous. Hepatitis $B$ vaccination coverage among Asian and Pacific Islander children - United States, 1998. Morbid Mortal Weekly Rep 2000; 49: 616-9.

24. Chao S, Le PV, Prapong W, Su J, So S. High prevalence of chronic hepatitis B (HBV) infection in Chinese Americans living in California (abstract). Hepatology 2004; 40(Suppl. 1): 717A.

25. LoK A, McMahon B. Chronic Hepatitis B. Hepatology 2001; 34: 1225-41.

26. Lok A S F, McMahon B J. Chronic Hepatitis B: update of recommendations. Hepatology 2004; 39: 857-61.

27. Chan H LY, Hussain M, LoK A S. Different hepatitis B virus genotypes are associated with different mutations in the core promoter and precore regions during hepatitis B e antigen seroconversion. Hepatology 1999; 29: 976-84.

28. LoK A S F, Hussain M, Cursano C, et al. Evolution of hepatitis $\mathrm{B}$ virus polymerase gene mutations in hepatitis $\mathrm{B}$ e antigen-negative patients receiving lamivudine therapy. Hepatology 2000; 32: 1145-53.

29. LoK A S F, Zoulim F, Locarnini S, et al. Monitoring drug resistance in chronic hepatitis B virus (HBV)-infected patients during lamivudine therapy: evaluation of performance of INNO-LiPA HBV DR assay. J Clin Microbiol 2002; 40: 3729-34.

30. Statistics Canada. Census 2001, www.statcan.ca. 2001.

31. EASL Jury. EASL International Consensus Conference on Hepatitis B. J Hepatol 2003; 39: S3-25.

32. Liaw Y F, Leung N W, Guan R, et al. Asian-Pacific consensus statement on the management of chronic hepatitis B: a 2005 update. Liver Int 2005; 25: 472-89.

33. Sherman M, Bain V, Villeneuve J P, et al. Management of viral hepatitis: a Canadian Consensus Conference 2003/ 2004. Can J Gastroenterol 2004; 18: 715-28.

34. Keeffe E, Dieterich D T, Han S H B, et al. A treatment algorithm for the management of chronic hepatitis $\mathrm{B}$ virus infection in the United States. Clin Gastroenterol Hepatol 2004; 2: 86-107.

35. Chan H, Leung N, Hussain M, Wong M, Lok A. Hepatitis B e antigen-negative chronic hepatitis B in Hong Kong. Hepatology 2000; 31: 763-8.

36. Kim W R, Benson J T, Therneau T M, Torgerson H A, Yawn B P, Melton L J III. Changing epidemiology of hepatitis B in a US community. Hepatology 2004; 39: 811-6. 